\title{
MENINGKATKAN HASIL BELAJAR SISWA DENGAN PENDEKATAN CONTEXTUAL TEACHING AND LEARNING (CTL) DALAM PENYELESAIAN SOAL CERITA MATEMATIKA SD
}

\author{
Ramli Sitorus \\ Dosen Jurusan PPSD Prodi PGSD FIP Unimed \\ Surel : sitorusramli105@ymail.com
}

\begin{abstract}
ABSTRAK
Penelitian tindakan kelas ini bertujuan untuk mengetahui peningkatan hasil belajar siswa dengan menggunakan pendekatan Contextual Teaching And Learning (CTL) pada penyelesaian soal cerita Matematika di kelas V SD. Subjek dalam penelitian tindakan kelas ini adalah siswa kelas V SD yang berjumlah 35 orang yang terdiri dari 20 siswa perempuan dan 15 siswa laki-laki. Teknik pengumpulan data yang digunakan dalam penelitian ini adalah dengan menggunakan data kuantitatif berupa test dan data kualitatif berupa observasi. Hasil observasi menunjukkan bahwa pada siklus I guru (peneliti) sudah dapat menerapkan pendekatan Contextual Teaching and Learning (CTL) dalam kegiatan pembelajaran matematika dengan baik dan pada siklus II guru (peneliti) dapat menerapkan pendekatan Contextual Teaching and Learning (CTL) dalam kegiatan pembelajaran matematika dengan sangat baik. Pada siklus I aktivitas siswa digolongkan dalam kategori cukup, sedangkan pada siklus II aktivitas siswa meningkat dan digolongkan dalam kategori baik.
\end{abstract}

Kata Kunci : Hasil Belajar, Pendekatan Contextual Teaching And Learning, Soal Cerita Matematika

\section{PENDAHULUAN}

Salah satu masalah yang dihadapi dunia pendidikan adalah masalah proses pembelajaran. Dalam proses pembelajaran siswa kurang didorong untuk mengembangkan kemampuan berpikir, proses pembelajaran di kelas selalu diarahkan pada kemampuan siswa untuk mendengarkan, menghafal informasi, tanpa menghubungkannya dengan kehidupan sehari-hari.

Pembelajaran Matematika menjadi kurang diminati siswa sekolah dasar (SD), karena banyak konsep atau topik yang abstrak, yang sulit dipelajari oleh siswa. Dari segi metode mengajar, permodelan kontekstual jarang dilaksanakan dalam pembelajaran sehingga banyak siswa kesulitan dalam memahami isi materi yang disampaikan oleh guru.

Sesuai hasil obsevasi dilapangan yang dilakukan terhadap kelas V SD Negeri 101785 Mabar, diperoleh bahwa hasil belajar siswa pada mata pelajaran Matematika di sekolah masih rendah khususnya dalam menyelesaikan soal cerita matematika. Data tersebut diperoleh dari hasil belajar sebelum terjadinya penelitian. Kesulitan yang dihadapi berhubungan dengan terbatasnya kemampuan siswa dalam membaca dan memahami isi cerita, menjawab pertanyaan isi cerita atau memahami apa yang diketahui dan apa yang ditanyakan, mengubah soal cerita menjadi kalimat matematika, menyelesaikan operasi hitung kalimat matematika, serta memvalidasi solusi 
yang diperoleh. Hal ini disebabkan belum optimal keterlibatannya dalam kegiatan pembelajaran dan kurangnya respon siswa karena pendekatan yang dilakukan guru belum memampukan siswa mengaplikasikan pengetahuan matematika yang dipelajari ke dalam kehidupan nyata sehari-hari. Kurangnya upaya guru meningkatkan respon siswa dalam mata pelajaran Matematika maka perlu diadakan perbaikan pembelajaran Matematika terhadap siswa kelas V yang berjumlah 35 orang.

Masalah tersebut tidak boleh dibiarkan berkelanjutan, oleh karenanya diperlakukan berbagai upaya yang dapat menunjang keberhasilan siswa dalam proses belajar. Banyak upaya yang dilakukan guru untuk meningkatkan hasil belajar siswa, salah satu cara yang dapat dilakukan guru adalah meningkatkan hasil belajar siswa melalui atau dengan menerapkan pendekatan Contextual Teaching and Learning (CTL) dalam pembelajaran Matematika. Dalam menerapkan pendekatan Contextual Teaching and Learning (CTL) guru diharapkan dapat menciptakan lingkungan belajar berpusat pada siswa, berorentasi pada kegiatan, mendorong siswa untuk terbuka dan berpikir bebas. Proses Contextual Teaching and Learning (CTL) mengandung proses mental yang lebih meningkat.

Pada awalnya, pendekatan Contextual Teaching and Learning (CTL) banyak ditetapkan dalam ilmu alam, namun demikian para ahli pendidikan ilmu pasti mengadopsi pendekatan Contextual Teaching and Learning (CTL) . Hal tersebut didasarkan pada asumsi pentingnya model Contextual Teaching and Learning (CTL) maka guru dapat menerapkan, menciptakan lingkungan belajar berpusat pada siswa, berorentasi pada kegiatan mendorong siswa untuk terbuka dan bepikir bebas. Model pembelajaran ini dalam penyampaian bahan pelajaran peserta didik sendiri diberi kesempatan untuk mencari, meneliti masalah, menggunakan tehnik pemecahan masalah.

Proses pembelajaran dengan menggunakan model Contextual Teaching and Learning (CTL) diharapkan dapat membantu peserta didik untuk menemukan permasalahan yang dihadapi sehari-hari. Jadi upaya meningkatkan hasil belajar inilah yang menarik untuk dikaji lebih jauh sehingga dalam proposal penelitian ini peneliti akan melakukan penelitian tentang "Meningkatkan Hasil Belajar Siswa Dengan Menggunakan Pendekatan Contextual Teaching And Learning (CTL) Dalam Penyelesaian Soal Cerita Matematika Di Kelas V SD Negeri 101785 Mabar T.P. 2012/2013".

\section{TINJAUAN TEORI}

\section{Hakikat Belajar}

Dalam kehidupannya manusia tidak akan pernah putus dari hal yang dikatakan belajar, tanpa disadari manusia tersebut, hari-hari yang dilaluinya semua adalah proses atau hasil dari belajar mulai dari belajar bicara, berjalan, sampai melakukan halhal kompleks yang berguna bagi kehidupannya.

Slameto (dalam Djamarah, Syaiful Bahri, 2008) mengatakan "bahwa belajar adalah suatu proses 
usaha yang dilakukan individu untuk memperoleh suatu perubahan tingkah laku yang baru secara keseluruhan, sebagai hasil pengalaman individu itu sendiri di dalam interaksi dengan lingkungannya.

Menurut Winkel (dalam Djamarah, Syaiful Bahri, 2006)“ Belajar adalah aktifitas mental atau psikis, yang berlangsung dalam interaksi aktif dengan lingkungan yang menghasilkan perubahan-perubahan dalam pengetahuan, pemahaman, keterampilan, nilai dan sikap.

\begin{tabular}{lcr}
\multicolumn{2}{c}{ Belajar menurut } & pendapat \\
modern & didefenisikan & sebagai \\
perubahan & kelakuan & (Nasution,
\end{tabular}
2000:15). Dengan demikian diharapkan apabila para pendidik menginginkan terjadinya belajar pada anak khususnya pelajaran Matematika, maka guru sebelum memasukkan anak pada proses belajar mengajar tersebut harus membuat persiapan yang terprogram serta memiliki tujuan yang jelas (Nasution, 2000:15).

Dari pernyataan diatas dapat disimpulkan bahwa belajar adalah tindakan dan perilaku siswa yang kompleks yang dialaminya sendiri yang didapat melalui kegiatan atau tingkah laku belajar yang saling bekerja sama secara terpadu, atau belajar dapat dipahami sebagai berusaha atau berlatih untuk mendapatkan kepandaian.

\section{Pengertian Belajar}

Belajar adalah perubahan prilaku yang terjadi karena latihan dan pengalaman. Perubahan dan kemampuan untuk berubah merupakan batasan dan makna yang terkandung dalam belajar. Untuk dapat disebut belajar, maka perubahan yang diakibatkan oleh belajar harus relatif menetap. Berapa lama periode itu berlangsung sulit ditentukan dengan pasti, tetapi perubahan itu hendaknya merupakan akhir dari suatu periode yang mungkin berlangsung berharihari, berbulan- bulan ataupun bertahunbertahun.

Menurut Dimyati \& Mujiono (2009:14), secara etimologi belajar memiliki arti "keseluruhan memperoleh kepandaian atau ilmu". Definisi ini memiliki pengertian bahwa belajar adalah sebuah kegiatan untuk mencapai kepandaian atau ilmu dan belajar merupakan usaha manusia untuk memenuhi kebutuhannya mendapatkan ilmu atau kepandaian yang belum dipunyai sebelumnya.

Belajar merupakan tindakan dan perilaku siswa yang kompleks. Menurut Dimyati \& Mudjiono (2009:7) menyatakan bahwa sebagai tindakan belajar hanya dialami oleh siswa sendiri karena siswa yang menjadi penentu terjadinya atau tidak terjadinya proses belajar. Menurut Slameto (dalam Dimyati \& Mudjiono, 2009 :2) pengertian secara psikologis belajar didefenisikan sebagai " suatu proses perubahan yaitu perubahan tingkah laku sebagai hasil dari interaksi dengan lingkungannya dalam memenuhi kebutuhan hidupnya".

Slameto (dalam Dimyati \& Mudjiono 2009:27) menyatakan bahwa " belajar adalah suatu proses usaha yang dilakukan setiap individu untuk memperoleh suatu perubahan tingkah laku secara keseluruhan sebagai hasil 
pengalaman individu tersebut dalam interaksi dengan lingkungannya". Skinner (Dimyati \& Mudjiono, 2009 ) berpandangan bahwa belajar adalah suatu perilaku, dimana pada saat orang belajar maka responnya baik, sebaliknya, bila ia tidak belajar maka responnya menurun.

Thursan (dalam Nasution, 2000: 34) menyatakan bahwa " belajar adalah suatu proses perubahan ditampakkan dalam bentuk peningkatan kualitas dan kuantitas tingkah laku seperti peningkatan kecakapan, pengetahuan, sikap, kebiasaan, pemahaman, keterampilan, daya pikir, dan lain- lain kemampuannya. Dari defenisi diatas, yang sangat perlu kita garis bawahi adalah bahwa peningkatan kualitas dan kuantitas tingkah laku seseorang diperlihatkan dalam bentuk bertambahnya kualitas dan kuantitas kemampuan orang itu dalam berbagai bidang.

Selanjutnya Gagne (dalam

Dimyati \& Mudjiono, 2009:10) menyatakan belajar merupakan kegiatan yang kompleks, setelah belajar orang memiliki keterampilan, pengetahuan, sikap, dan nilai.

Dari berbagai pendapat di atas dapat disimpulkan bahwa belajar adalah serangkaian kegiatan jiwa raga untuk memperoleh suatu perubahan tingkah laku sebagai hasil dari pengalaman individu dalam interaksi dengan lingkungannya yang menyangkut kognitif, afektif, dan psikomotor. Agar proses belajar berhasil, sebelum kegiatan belajar dikelas seorang guru perlu menyiapkan atau merencanakan berbagai pengalaman yang akan diberikan kepada siswa dimana pengalaman belajar tersebut harus sesuai dengan tujuan yang ingin dicapai.

Pengalaman merupakan interksi antara individu dengan lingkungannya sebagai sumber belajarnya. Jadi, belajar disini diartikan sebagai proses perubahan perilaku tetap dari yang belum tahu menjadi tahu, dari yang tidak paham menjadi paham, dari yang kurang terampil menjadi terampil, dan dari kebiasaan lama menjadi kebiasaan baru, serta bermanfaat bagi lingkungan maupun individu itu sendiri.

\section{Hasil Belajar}

Hasil belajar adalah kemampuan yang dimiliki siswa setelah siswa menerima pengalaman belajarnya. Hasil belajar mempunyai peranan penting dalam proses pembelajaran. Proses penilaian terhadap hasil belajar dapat memberikan informasi kepada guru tentang kemajuan siswa dalam upaya mencapai tujuan-tujuan belajarnya melalui kegiatan belajar. Selanjutnya dari informasi tersebut guru dapat menyusun dan membina kegiatankegiatan siswa lebih lanjut, baik untuk keseluruhan kelas maupun individu.

Sudjana (2009:3) mengatakan hasil belajar pada hakikatnya perubahan tingkah laku dari yang tahu menjadi tahu, tingkah laku sebagai hasil belajar dalam pengertian yang luas mencakup bidang kognitif, afektif, dan psikomotoris. Banyak aktivitas pada belajar yang dilakukan siswa, tidak hanya memperhatikan penjelasan guru semata, tetapi dapat melakukan tanya jawab, baik terhadap guru maupun antar siswa sendiri, melakukan diskusi dalam 
kelompok belajar yang kecil atau besar, melakukan pengamatan terhadap diri sendiri maupun lingkungannya,bahkan menurut Slameto (2003:13) mengatakan siswa harus melakukan aktivitas dalam mengadakan percobaan (usaha) dalam bidang kognitif, psikomotor, afektif dalam belajar, jadi belajar akan lebih menarik dan efektif karena banyak aktivitas yang akan dilakukan.

Aktivitas atau kegiatan belajar tersebut tidak akan berjalan dengan baik tanpa adanya partisipasi siswa itu tersebut. Selain itu guru bahkan orang tua turut berpartisipasi untuk memfasilitasi aktivitas belajar siswa. Guru harus berpartisipasi untuk mengarahkan, memantau, membantu siswa, menyediakan sumber-sumber belajar, mengatur, menilai kemajuan siswa, mengadakan evaluasi, dan menciptakan kondisi yang baik untuk seluruh aktivitas siswa agar dapat mencapai tujuan yang diharapkan. Orangtua juga turut berpartisipasi dalam mengawasi siswa, khususnya pada saat siswa berada di rumah.

Menurut Dimyati \& Mudjiono (2009) menyatakan hasil belajar merupakan hal yang dapat dipandang dari dua sisi yaitu sisi siswa dan dari sisi guru. Dari sisi siswa, hasil belajar merupakan tingkat perkembangan mental yang lebih baik bila dibandingkan pada saat sebelum belajar. Tingkat perkembangan mental tersebut terwujud pada jenis-jenis ranah kognitif, afektif, dan psikomotor, (http://whandi.net/2009/10/edukasi/pengertian-hasil-belajar,html).

Menurut Benyamin Bloom
(dalam Sudjana 2009:22) mengklasifikasi hasil belajar menjadi tiga ranah, yakni:

1) Ranah kognitif berkenaan dengan hasil belajar intelektual, terdiri dari pengetahuan, pemahaman, aplikasi, analisis, sintesis, dan evaluasi.

2) Ranah afektif berkenaan dengan sikap, terdiri dari penerimaan, jawaban, penilaian, organisasi, dan internalisasi.

3) Ranah psikomotoris berkenaan dengan hasil belajar keterampilan dan kemampuan bertindak, terdiri dari gerakan refleks, keterampilan gerakan dasar, kemampuan perseptual, keharmonisan, gerakan keterampilan kompleks, gerakan ekspresif dan interpretatif.

Berdasarkan pendapat di atas dapat disimpulkan bahwa hasil belajar akan tercapai dengan baik jika seluruh kegiatan atau aktivitas belajar berjalan dengan baik, untuk mengetahui hasil belajar atau untuk menilai hasil belajar siswa dapat dilakukan beberapa cara, misalnya dengan nilai tes dan observasi. Dengan cara ini dapat diketahui tingkat hasil belajar yang telah dicapai siswa.

\section{Faktor- Faktor Yang Mempengaruhi Hasil Belajar}

Dalam belajar, banyak sekali faktor yang mempengaruhinya. Dari sekian banyak faktor yang mempengaruhi belajar, Slameto (dalam Dimyati \& Mudjiono, 2009 : 54) menggolongkan faktor-faktor yang mempengaruhi belajar menjadi dua golongan,yaitu:

Faktor intern adalah faktor yang ada dalam diri individu yang sedang belajar, yang termasuk faktor intern ialah : 
1). Faktor Jasmaniah, yakni : faktor kesehatan dan faktor tubuh.

2). Faktor Psikologis, yakni: inteligensi, perhatian, minat, bakat, motif, kematangan, kesiapan.

\section{3). Faktor Kelelahan.}

Faktor ekstern adalah faktor yang ada di luar individu yang sedang belajar,dan yang termasuk faktor ekstern ialah :

1). Faktor Keluarga, yakni : cara orang tua mendidik, relasi antar anggota keluarga, suasana rumah, keadaan ekonomi keluarga, pengertian orang tua, latar belakang kebudayaan.

2). Faktor Sekolah, yakni : metode mengajar, kurikulum, relasi guru dengan siswa, relasi siswa dengan siswa, disiplin sekolah, alat pelajaran, waktu sekolah, standar pelajaran di atas ukuran, keadaan gedung, metode belajar, tugas rumah.

3). Faktor Masyarakat, yakni : kegiatan siswa dalam masyarakat, mass media, teman bergaul, bentuk kehidupan masyarakat.

Berdasarkan pendapat di atas dapat disimpulkan bahwa dengan mengetahui faktor-faktor belajar maka guru dapat merancang pembelajaran atau menciptakan kondisi belajar yang mengoptimalkan hasil belajar siswa yang akan diperoleh. Dalam pembelajaran guru juga memiliki pengaruh besar terhadap proses dan hasil belajar siswa, karena seperti yang telah dijelaskan, guru harus memfasilitasi sampai memotivasi siswa untuk belajar, jika guru tidak berperan aktif kegiatan pembelajaran pasti tidak berjalan dengan baik.

\section{Pengertian Pendekatan Kontekstual}

Pendekatan kontekstual /

Contextual Teaching and Learning (CTL) merupakan salah satu model atau konsepsi pembelajaran yang membantu guru mengaitkan konten mata pelajaran dengan situasi dunia nyata dan memotivasi siswa membuat hubungan antara pengetahuan dan penerapannya dalam kehidupan mereka. Kontekstual adalah sebuah pendekatan pembelajaran yang mengakui dan menunjukkan kondisi alamiah dari pengetahuan yang menjadikan pengalaman lebih relevan dan berarti bagi siswa dalam membangun pengetahuan yang akan mereka terapkan dalam pembelajaran seumur hidup.

Johnson (2007:295) menyatakan bahwa "Contextual Teacher and Learning (CTL) adalah suata proses pendidikan yang bertujauan membantu siswa melihat makna dalam bahan pelajaran yang mereka pelajari dengan cara menghubungkannya dengan konteks kehidupan mereka sehari-hari, yaitu dengan konteks lingkungan pribadinya, sosialnya, dan budayanya".

Menurut Suprijono (2010:79) bahwa "pendekatan kontekstual adalah konsep yang membantu guru mengaitkan antara materi yang diajarakannya dengan situasi dunia nyata dan mendorong peserta didik membuat hubungan antara pengetahuan yang dimilikinya dengan penerapannya dalam kehidupan mereka sebagai anggota keluarga dan masyarakat yang bertujuan membantu peserta didik memahami makna bahan pelajaran yang mereka pelajari”. 
Dari pendapat-pendapat di atas dapat ditarik kesimpulan bahwa pembelajaran kontekstual merupakan pembelajaran yang memahami makna materi pelajaran yang dipelajari siswa dengan menghubungkan materi pembelajaran dengan konteks kehidupan siswa, sehingga siswa memiliki pengetahuan atau keterampilan secara fleksibel dengan melibatkan tujuh komponen utama pembelajaran kontekstual.

\section{Tujuh Komponen Pendekatan Kontekstual \\ Kontruktivisme (constructivism)}

Kontruktivisme adalah proses membangun atau menyusun pengetahuan baru dalam struktur kognitif siswa berdasarkan pengalamannya.

Menurut Trianto (2009:113) bahwa,"Kontruktivisme merupakan landasan berfikir (Filosofi) bagi pendekatan kontekstual (CTL) yaitu pengetahuan dibangun oleh manusia sedikit demi sedikit dan harus bisa mengkonstuksi pengetahuan itu dan memberi makna melalui pengalaman nyata". Pengetahuan Riil bagi para siswa adalah sesuatu yang di bangun atau ditemukan oleh siswa itu sendiri dan mentransformasikan suatu informasi ke situasi lain. Jadi pengetahuan bukanlah seperangkat fakta, konsep atau kaidah yang diingat siswa, tetapi siswa harus merekonstruksi pengetahuan itu kemudian memberi makna melalui pengalaman nyata.

Dari pendapat di atas dapat disimpulkan kontuktivisme merupakan proses membangun atau menyusun pengetahuan baru dalam struktur kognitif berdasarkan pengalaman baru.

\section{Menemukan (inquiry)}

Menurut Trianto (2009:114) menyatakan bahwa "Inkuiri merupakan bagian inti dari kegaitan pembelajaran berbasis kontekstual. Pengetahuan dan keterampilan yang diperoleh siswa diharapkan bukan hasil mengingat seperangkat fakta-fakta, tetapi hasil dari menemukan sendiri". Guru harus mampu merancang kegiatan yang merujuk pada kegiatan menemukan, apapun yang diajarkannya.

$$
\text { Adapun Langkah-langkah }
$$

kegiatan menemukan (inquiry) : (1) merumuskan masalah (dalam mata pelajaran apa pun), (2) mengamati atau melakukan observasi, (3) menganalisis dan menyajikan hasil dalam tulisan, gambar, laporan, bagan, tabel, dan karya lainnya, (4) mengkomunikasikan atau menyajikan hasil karya pada pembaca, teman sekelas, guru atau audiensi yang lain

Jadi Inquiry adalah proses berfikir secara otomatis yang merupakan pengajaran dan keterampilan yang diperoleh siswa diharapkan bukan hasil mengingat seperangkat fakta-fakta tetapi hasil dari menemukan sendiri.

\section{Bertanya (Questioning)}

Dalam konsep ini tanya jawab dilakukan baik oleh guru maupun siswa. Menurut Bandono (dalam Trianto 2009:7) bahwa, "Pertanyaan guru digunakan untuk memberikan kesempatan kepada siswa untuk berfikir 
kritis dan mengevaluasi cara berfikir siswa, sedangkan pertanyaan siswa merupakan wujud keingintahuan".

Menurut Trianto (2009:115) menyatakan bahwa :Dalam sebuah pembelajaran yang produktif, kegiatan bertanya berguna untuk menggali informasi, mengecek pemahaman siswa, membangkitkan respons kepada siswa, mengetahui sejauh mana keingintahuan siswa, mengetahui hal-hal yang sudah diketahui siswa, memfokuskan perhatian siswa pada sesuatu yang dikehendaki guru, untuk membangkitkan lebih banyak lagi pertanyaan siswa dan untuk menyegarkan kembali pengetahuan siswa.

Kegiatan bertanya sangat berguna untuk : (a) menggali informasi tentang kemampuan siswa dalam penguasaan materi pembelajaran, (b) membangkitkan motivasi siswa dalam belajar, (c) merangsang keingintahuan siswa pada sesuatu yang diinginkan, (e) membimbing siswa untuk menyimpulkan sesuatu.

Berdasarkan pendapat di atas dapat disimpulkan bahwa Kegiatan bertanya dapat diterapkan antar siswa dengan siswa dengan siswa, antara guru dengan siswa, antara siswa dengan orang lain yang didatangkan ke kelas. Aktifitas bertanya dapat ditemukan ketika siswa berdiskusi, bekerja dalam kelompok, ketika menemui kesulitan, ketika mengamati dan sebagainya. Bertanya dalam pembelajaran dipandang bukan hasil mengingat seperangkat fakta-fakta tetapi hasil dari menemukan.

\section{Masyarakat belajar (Learning \\ Community)}

Menurut Akhmad Sudrajat (2008) "Learning Community adalah sekelompok orang yang terkait dalam kegiatan belajar, bekerjasama dengan orang lain, tukar pengalaman dan berbagi ide".. Beberapa hal yang dapat diwujudkan umtuk mengembangkan Learning Community di kelas antara lain : (a) pembentukan kelompok kecil, (b) pembentukan kelompok besar, (c) mendatangkan nara sumber ke kelas, (d) bekerja sama antar teman yang tahu ke teman yang belum tahu, (e) bekerja kelompok dengan kelas diatasnya.

Trianto (2009:116) menyatakan bahwa, "masyarakat belajar bisa terjadi apabila ada proses komunikasi dua arah". Seorang guru yang mengajari siswanya bukan contoh masyarakat belajar karena komunikasi hanya terjadi satu arah, yaitu informasi hanya datang dari guru ke arah siswa, tidak ada arus informasi yang perlu dipelajari guru yang datang dari arah siswa. Dalam masyarakat belajar, dua kelompok (atau lebih) yang terlibat dalam komunikasi pembelajaran saling belajar. Seseorang yang terlibat dalam kegiatan masyarakat belajar memberi informasi yang diperlukan dari teman belajarnya dan sekaligus juga meminta informasi yang diperlukan dari teman belajarnya.

Setiap siswa dapat belajar dari siswa lain, maka setiap siswa bisa menjadi sumber belajar dan dalam hal ini siswa akan sangat kaya dengan pengetahuan dan pengalaman.

\section{Pemodelan (modeling)}


Menurut pendapat Suprijono (2010:88) menyatakan bahwa, "Pemodelan adalah kegiatan yang akan mendemonstrasikan suatu kinerja yang dipelajari siswa dapat mencontoh atau melakukan sesuatu sesuai dengan model yang telah diberikan dan kemudian ditiru". Sedangkan Trianto (2009:117) menyatakan bahwa, "pemodelan akan lebih mengefektifkan pelaksanaan pembelajaran dengan pendekatan kontekstual untuk ditiru, diadaptasi atau dimodifikasi. Dengan adanya suatu model untuk dijadikan contoh biasanya akan lebih dipahami atau bahkan bisa menimbulkan ide baru".

Modeling merupakan azas yang cukup penting dalam pendekatan kontekstual, sebab melalui modeling siswa dapat terhindar dari pembelajaran yang teoritis-abstrak yang dapat memungkinkan terjadinaya variabelisme. Jadi Modeling adalah proses pembelajaran dengan memperagakan sebagi contoh yang dapat ditiru oleh siswa.

\section{Refleksi (Reflection)}

Refleksi merupakan bagian penting dalam pembelajaran dengan Contextual Teaching and Learning (CTL). Menurut Trianto (2009:117) bahwa "Refleksi adalah cara berfikir kembali tentang materi apa yang baru dipelajari, merenungkan lagi aktifitas yang telah dilakukan atau mengevaluasi kembali tentang apa yang telah dipelajari yang telah dilakukan". Pada akhir pembelajaran guru menyisakan waktu untuk memberikan kesempatan bagi para siswa melakukan refleksi, gunanya ialah agar siswa tahu akan kekurangan atau kelemahan dalam memahami materi yang telah dipelajari pada masing-masing siswa.

Jadi dapat disimpulkan refleksi adalah prsoses pengendapan yang telah dipelajari yang akan dilakukan dengan mengurutkan kembali kejadian-kejadian atau peristiwa pembelajaran yang di laluinya.

\section{Penilaian yang autentik (Authentic Assessment)}

Menurut Trianto (2009:118) bahwa, "Authentic Assesment adalah proses pengumpulan data yang bisa memberikan gambaran perkembangan belajar siswa. Gambaran perkembangan belajar siswa perlu diketahui oleh guru agar bisa memastikan bahwa siswa mengalami proses pembelajaran dengan benar. Penilaian yang dilakukan secara komprehensif berkenaan dengan seluruh aktifitas pembelajaran yang meliputi proses dan produk belajar sehingga seluruh usaha siswa yang telah dilakukan mendapat penghargaan".

Ciri-ciri penilaian autentik adalah (a) harus mengukur semua aspek pembelajaran: proses, kinerja, dan produk. (b) dilaksanakan selama dan sesudah proses pembelajaran berlangsung, (c) menggunakan berbagai cara dan sumber, (d) tes hanya salah satu alat pengumpul data penilaian, (e) tugas-tugas yang diberikan ke siswa harus mencerminkan bagian-bagian kehidupan siswa yang nyata setiap hari, dan (f) penilaian harus meningkatkan kedalaman pengetahuan dan keahlian siswa, bukan keluasannya (kuantitas).

Karakteristik penilaian autentik adalah (a) dilaksanakan selama dan sesudah proses pembelajaran 
berlangsung, (b) dapat digunakan untuk formatif maupun sumatif, (c) yang diukur keterampilan dan performansi, bukan mengingat fakta, (d) berkesinambungan, (e) terintegrasi, dan (f) dapat digunakan sebagai feedback.

Penilaian merupakan proses pengumpulan data yang memberikan gambaran perkembangan belajar siswa. Gambaran perkembangan perlu diketahui oleh guru agar bisa mengetahui apakah siswa mengalami proses pembelajaran dengan benar. Jadi, Penilaian autentik adalah proses yang dilakukan guru untuk mengumpulkan informasi tentang perkembangan informasi tentang perkembangan belajar yang dilakukan siswa.

Dapat disimpulkan bahwa ketujuh komponen pendekatan kontekstual saling berkaitan erat dalam proses pembelajaran, sehingga siswa dapat terampil dalam berfikir dan memahami pentingnya mempelajari pengetahuan dengan penerapannya dalam kehidupan siswa tersebut.

\section{Kelebihan dan Kekurangan Pendekatan Kontekstual}

Menurut Kunandar (2007: 45) kelebihan dan kekurangn pembelajaran kontekstual dapat di jelaskan sebagai berikut. Kelebihan pembelajaran Kontekstual yaitu : (1) pembelajaran yang menghubungkan antara materi yang diajarkan dengan situasi dunia nyata siswa ; (2) melibatkan siswa secara aktif dalam proses pembelajaran ; (3) melatih siswa untuk memecahkan masalah, menemukan sesuatu yang berguna bagi dirinya dan bergulat dengan ide-ide serta mampu mengidentifikasikan dan menyimpulkan materi yang dipelajarinya ; (4) membangkitkan motivasi siswa dalam belajar ; (5) merangsang keingintahuan siswa terhadap materi pelajaran ; (6) menciptakan proses pembelajaran dalam bentuk kelompok belajar ; (7) merefleksikan pengetahuan siswa dengan materi yang baru saja dipelajari sebagai struktur pengetahuan yang baru ; (8) melaksanakan penilaian sepanjang proses kegiatan pembelajaran ; (9) mendorong siswa untuk mengartikan apa makna belajar dan apa manfaatnya ; (10) memposisikan siswa sebagai pihak yang memerlukan bekal untuk hidupnya nanti.

Kekurangan CTL bersumber pada dua faktor yaitu faktor dari dalam (intern) dan faktor dari luar (ekstern). Faktor dari dalam yaitu sebagai berikut ; (1) guru harus mempersiapkan pembelajaran secara matang, disamping itu memerlukan lebih banyak tenaga, pemikiran dan waktu ; (2) agar proses pembelajaran berjalan dengan lancar maka dibutuhkan dukungan, fasilitas, alat, dan biaya yang cukup memadai ; (3) selama kegiatan berlangsung, ada kecenderungan topik permasalahan yang sedang dibahasa meluas. Sehingga banyak yang tidak sesuai dengan waktu yang telah ditentukan.

\section{Ciri-ciri Pembelajaran Kontekstual}

Menurut Kunandar (2007:298) adapun Ciri-ciri pembelajaran kontekstual antara lain : (a) adanya kerjasama antar semua pihak. (b) menekankan pentingnya pemecahan masalah. (c) bermuara pada keragaman 
konteks kehidupan siswa yang berbedabeda. (d) saling menunjang. (e) menyenangkan, tidak membosankan. (f) belajar dan bergairah. (h) pembelajaran terintegrasi. (i) menggunakan berbagai sumber. (j) siswa aktif.

\section{Karakteristik \\ Pembelajaran Kontekstual}

Menurut Johnson (2007: 65) ada delapan komponen utama dalam sistem pembelajaran kontekstual yaitu sebagai berikut : (a) melakukan hubungan yang bermakna. (b) melakukan kegiatankegiatan yang signifikan. (c) belajar yang diatur sendiri. (d) bekerja sama. (e) berfikir kreatif dan kritis. mengasuh atau memelihara pribadi siswa. (g) mencapai standar yang tinggi. (h) menggunakan penilaian autentik.

\section{Langkah-Langkah Pembelajaran CTL}

Sebuah kelas dikatakan menggunakan model pembelajaran CTL jika menerapkan ketujuh komponen CTL dalam pembelajaran (Nurhadi dan Senduk 2003:31).

Lebih lanjut Trianto (2009:106), menyatakan bahwa penerapan CTL dalam kelas cukup mudah. Secara garis besar, langkahnya adalah sebagai berikut:

a. Kembangkan pemikiran bahwa anak akan belajar lebih bermakna dengan cara bekerja sendiri, menemukan sendiri dan mengkonstruksi sendiri pengetahuan dan keterampilan barunya!

b. Laksanakan sejauh mungkin kegiatan inquiry untuk semua pihak! c. Kembangkan sifat ingin tahu siswa dengan bertanya!

d. Ciptakan 'masyarakat belajar' (belajar dalam kelompok-kelompok)

e. Hadirkan 'model' sebagai contoh pembelajaran!

f. Lakukan refleksi di akhir pertemuan!

g. Lakukan penilaian yang sebenarnya dengan berbagai cara!

\section{Hakikat Pembelajaran Matematika}

Merujuk pada berbagai pendapat para ahli matematika SD dalam mengembangkan motivasi dan kompetensi siswa, maka guru hendaknya dapat menyajikan pembelajaran yang efektif dan efisien, sesuai dengan kurikulum dan pola pikir siswa. Dalam mengajarkan matematika, guru harus memahami bahwa setiap kemampuan siswa berbeda-beda, serta tidak semua siswa menyenangi pelajaran matematika.

Konsep-konsep pada kurikulum matematika SD dapat dibagi menjadi tiga kelompok besar, yaitu penanaman konsep dasar, pemahaman konsep, dan pembinaan keterampilan. Memang, tujuan akhir pembelajaran matematika di SD ini yaitu agar siswa terampil dalam menggunakan berbagai konsep matematika dalam kehidupan seharihari. Akan tetapi, untuk menujuk tahap keterampilan tersebut harus melalui langkah-langkah benar yang sesuai dengan kemampuan dan lingkungan siswa. (Heruman, 2007:2). Belajar Matematika berguna untuk mengembangkan kemampuan berkomunikasi dengan simbol-simbol serta ketajaman penalaran yang dapat memperjelas dan menyelesaikan 
permasalahan-permasalahan dalam kehidupan sehari-hari, (Depdiknas, 2006). Rusefendi (dalam Heruman 2007:1) mengatakan bahwa matematika "adalah bahasa simbol; ilmu dedukatif yang tidak menerima pembuktian secara indukatif, ilmu tentang pola keteraturan dan struktur yang terorganisir, mulai dari unsur yang didefenisikan, ke aksioma atau postulat dan akhirnya ke dalil. Sedangkan hakikat matematika menurut Soedjadi (dalam Heruman 2007), yaitu objek tujuan abstrak, bertumpu pada kesepakatan dan pola pikir deduktif. Hal ini berarti belajar matematika adalah "belajar konsepkonsep dan struktur-struktur yang terdapat dalam bahasan yang dipelajari serta mencari hubungan antara konsepkonsep dan struktur-struktur tersebut serta kebenaran dalam matematika akan dikembangkan secara logis".

Berdasarkan pendapat di atas dapat disimpulkan bahwa seseorang di katakana belajar Matematika, apabila seseorang tersebut melakukan kegiatan yang mengakibatkan perubahan tingkah laku yang berkaitan dengan Matematika. Belajar Matematika merupakan aktifitas mental untuk memahami struktur, hubungan serta konsep dalam Matematika untuk kemudian di terapkan dalam situasi lain.

\section{Tujuan Pembelajaran Matematika}

Belajar matematika merupakan suatu proses aktif yang sengaja untuk memperoleh pengetahuan baru dalam mengembangkan struktur-struktur yang terdapat dalam bahasan matematika, serta mencari hubungannya untuk untuk mendapat suatu pengertian dan mengaplikasikan konsep dalm situasi yang nyata, sehingga arah belajar matematika umumnya menuju kepengabstrakan yang semakin kompleks. Metematika juga berkaitan dengan ide-ide atau gagasan-gagasan. Struktur dan hubungannya yang diatur secara logis sehingga matematika itu berkaitan dengan konsep-konsep abstrak.

Dari pendapat di atas, guru dituntut untuk mampu menguasai bahan ajar, serta melaksanakan strategi, metode, model, atau pendekatan yang relevan dalam menyampaikan materi. Hal ini penting mengingat apa yang dibahas dalam mempelajari matematika bukanlah benda kongkrit atau apa yang dapat dipegang atau diraba. Meskipun berasal dari permasalahan nyata atau kongkrit mempelajari matematika haruslah bertahap atau beraturan serta berdasarkan pengalaman belajar.

\section{Soal Cerita Matematika}

Permasalahan matematika yang berkaitan dengan kehidupan nyata biasanya dituangkan melalui soal-soal berbentuk cerita (verbal). Menurut Abidia (dalam Marsudi Raharjo, 2009: 56), soal cerita adalah soal yang disajikan dalam bentuk cerita pendek. Cerita yang diungkapkan dapat merupakan masalah kehidupan seharihari atau masalah lainnya. Bobot masalah yang diungkapkan akan mempengaruhi panjang pendeknya cerita tersebut. Makin besar bobot masalah yang diungkapkan, memungkinkan semakin panjang cerita yang disajikan. Sementara itu, menurut Haji (dalam Marsudi Raharjo, 2009: 
45), soal yang dapat digunakan untuk mengetahui kemampuan siswa dalam bidang matematika dapat berbentuk cerita dan soal bukan cerita / soal hitungan. Dalam hal ini, soal cerita merupakan modifikasi dari soal-soal hitungan yang berkaitan dengan kenyataan yang ada di lingkungan siswa.

Berdasarkan pendapat diatas bahwa dalam pembelajaran matematika, soal cerita hanyalah sebuah bentuk dari metode atau cara dalam pemahaman dan penguasaan materi yang sedang berlangsung atau diajarkan. Untuk dapat menyelesaikan soal cerita, siswa harus menguasai hal-hal yang dipelajari sebelumnya. Di samping itu, siswa juga harus menguasai materi prasyarat, seperti rumus, teorema, dan aturan/hukum yang berlaku dalam matematika. Pemahaman terhadap halhal tersebut akan membantu siswa memahami maksud yang terkandung dalam soal-soal cerita tersebut.

\section{Faktor Persekutuan Terbesar (FPB) dan Kelipatan Persekutuan Terkecil (KPK)}

(FPB) dari dua bilangan dapat ditentukan dengan langkah-langkah berikut:

a. Tuliskan kedua bilangan itu sebagai perkalian faktor prima

b. Tentukan perkalian faktor yang sama dari kedua bilangan

c. Jika prima yang sama tersebut pengkatnya berbeda, tentukan faktor prima yang pangkatnya terkecil dan kalikan ( misalnya : $2^{2}$ dan $2^{3}$, diambil $2^{2}$ )
Soal cerita dalam penggunaan FPB:

Pak Yudi mempunyai 24 pensil dan 30 buku. Pensil dan buku akan dibagikan kepada siswanya sehingga setiap siswa mendapatkan pensil dan buku dengan jumlah yang sama. Paling banyak, berapa siswa yang diberi pensil dan buku?

Jawab:

Diketahui: 24 pensil dan 30 buku

Ditanyakan: paling banyak, berapa siswa yang dapat diberi pensil dan buku dengan jumlah sama?

\section{Penyelesaian :}

Untuk menyelesaikan soal ini, kamu harus mencari FPB dari 24 dan 30.

$24=2 \times 2 \times 2 \times 3=2^{3} \times 3$

$30=2 \times 3 \times 5$

FPB dari 24 dan $30=2 \times 3=6$

Jadi, paling banyak siswa yang dapat diberi pensil dan buku dengan jumlah sama oleh pak yudi adalah 6 siswa. Setiap siswa mendapat 4 pensil dan 5 buku.

Sedangkan kelipatan persekutuan terkecil (KPK) dari dua bilangan dapat di tentukan dengan langkah-langkah berikut:

a. Tuliskan kedua bilangan itu sebagai faktorisasi prima

b. Tentukan perkalian semua faktor prima dari kedua bilangan itu

c. Untuk faktor yang sama, tentukan faktor pangkatnya terbesar ( misalnya: $3^{2}$ dan $3^{3}$, di ambil $3^{3}$ ) dan dikalikan.

Contoh soal cerita dalam penggunaan KPK:

Ibu Tina pergi ke pasar setiap 6 hari sekali, sedanglan ibu Heni setiap 8 hari sekali. Jika mereka bersama-sama pergi 
ke pasar pada tanggal 1 Maret 2004, kapan mereka pergi ke pasar bersamasama untuk kedua kalinya?

\section{Jawab:}

Diketahui:

Ibu Desi pergi ke pasar setiap 6 hari sekali

Ibu Yeni pergi ke pasar setiap 8 hari sekali

Pergi ke pasar bersama-sama tanggal 1 maret 2004

Ditanyakan: pergi ke pasar bersamasama untuk kedua kalinya?

\section{Penyelesaian :}

Untuk menjawab soal ini, kamu harus mencari KPK dari 6 dan 8

$6=2 \times 3$ dan $8=2 \times 2 \times 2=2^{3}$

KPK dari 6 dan 8 adalah $2^{3} \times 3=8 \times 3$ $=24$

Jadi, ibu Tina dan ibu Heni pergi ke pasar bersama-sama untuk yang kedua kalinya setelah 24 hari, yaitu 1 Maret $2004+24$ hari = 25 Maret 2004

Dari penjabaran diatas dapat di simpulkan bahwa soal cerita yang dimaksudkan dalam pemecahan masalah FPB dan KPK adalah salah satu cara pemahaman siswa dalam mengerjakan soal. Soal cerita juga banyak kita jumpai diberbagai persoalan pelajaran lainnya, soal cerita tersebut adalah suatu bentuk akan pemahaman konsep pada materi tersebut. Apabila siswa telah memahami dalam bentuk soal cerita, maka persoalan apapun pada mata pelajaran yang lainnya, siswa akan dengan mudah menjawab maksud atau arti dari pertanyaan tersebut dalam bentuk soal cerita.

\section{Kerangka Konseptual}

Berdasarkan penyajian deskripsi teoritik dapat disusun suatu kerangka berfikir untuk memperjelas arah dan maksud penelitian.

Keberhasilan proses belajar mengajar dapat dilihat dari prestasi belajar siswa. Banyak faktor yang mempengaruhi keberhasilan siswa diantaranya adalah pendekatan pembelajaran yang digunakan guru dan hasil belajar siswa.

Penggunaan pendekatan pembelajaran dalam proses belajar mengajar sangat berpengaruh terhadap prestasi belajar siswa. Keanekaragaman pendekatan mengajar yang ada pada saat ini merupakan alternatif yang dapat digunakan oleh guru untuk memilih pendekatan mana yang sesuai dengan materi yang akan disampaikan.

Dalam penelitian ini digunakan pembelajaran dengan pendekatan kontekstual yaitu konsep belajar yang membantu guru menghubungkan antara materi pelajaran yang diajarkannya dengan situasi dunia nyata siswa dan mendorong siswa membuat hubungan antara pengetahuan yang dimilikinya dengan penerapannya dalam kehidupan sehari-hari.

Dalam pembelajaran kontekstual, guru menyatukan antara materi pelajaran yang diajarkan dengan situasi nyata. Tahapan model pendekatan kontekstual meliputi empat tahapan, yaitu : invitasi, eksplorasi, penjelasan dan solusi, dan pengambilan tindakan.

Pendekatan pembelajaran yang sesuai dan adanya hasil belajar kepada siswa, akan membantu anak memperoleh suatu prestasi belajar yang diharapkan. Pendekatan konsektual atau disebut dengan Contextual Teaching 
and Learning (CTL) adalah suatu pendekatan dalam pembelajaran yang membantu guru untuk mengaitkan antara materi ajar dengan situasi dunia nyata siswa, yang dapat mendorong siswa membantu hubungan antara pengetahuan yang dipelajari dengan penerapannya dalam kehidupan para siswa sebagai anggota keluarga dan masyarakat. Dalam pelaksanaan pendekatan konsektual, guru lebih dahulu menerangkan sub materi pokok mengomentari persoalan faktual, kemudian siswa dilibatkan secara penuh untuk dapat menemukan materi yang dipelajari dan menghubungkan dengan situasi nyata. Maka hasil belajar siswa dapat meningkat dengan menggunakan pendekatan konsektual. Mengingat bahwa pentingnya penggunaan pendekatan kontekstual dalam pelajaran Matematika akan membantu para guru dan siswa dalam proses belajar mengajar. Dengan demikian penggunaan pendekatan kontekstual dalam menyelesaikan soal cerita matematika materi FPB dan KPK diharapkan dapat meningkatkan hasil belajar matematika siswa. Dan setelah kegiatan mengajar selesai diadakan tes untuk mengukur pemahaman siswa.

\section{Prosedur Penelitian}

Penelitian ini langsung dilakukan didalam kelas meliputi kegiatan pelaksanaan PTK berupa perencanaan awal dan observasi untuk mengidentifikasi permasalahan yang terjadi di kelas.Pada penelitian ini, peneliti mencari pemecahan masalah pembelajaran dalam mata pelajaran Matematika kelas V SD Negeri 101785 Mabar.
Pelaksanaan PTK direncanakan akan dilakukan dua kali pertemuan setiap siklus:

\section{Siklus I}

\section{Tahap Perencanaan}
a. Menyusun Rencana Pelaksanaan Pembelajaran.
b. Membagi kelompok belajar siswa,
c. Membuat skenario pembelajaran sesuai dengan pendekatan kontekstual.
d. Membuat sumber dan bahan yang digunakan dalam pembelajaran.
e. Membuat lembar observasi tentang keaktifan belajar siswa.

\section{Tahap Pelaksanaan}

Pada tahap ini kegiatan yang dilakukan adalah melaksanakan pembelajaran sesui dengan scenario pembelajaran yang telah disusun dengan menonjolkan tindakan yang diterapkan yaitu penggunaan pendekatan kontekstual dalam proses belajar mengajar. Kegiatan yang dilakukan antara lain:

a. Guru melakukan apersepsi

b. Guru menjelaskan materi pelajaran

c. Guru membagi siswa ke dalam 7 kelompok yang terdiri dari 5 orang dalam 1 kelompok

d. Guru menjelaskan tentang materi soal cerita matematika dalam FPB dan KPK (konstruktivisme)

e. Guru menyuruh siswa mencari maksud dari pertanyaan dalam soal cerita (inkuiri)

f. Guru memberikan kesempatan kepada siswa untuk menanyakan kembali penjelasan dari soal cerita yang di sampaikan (bertanya) 
g. Guru mulai memperhatikan kerja siswa dengan mengisi lembar observasi

h. Guru menyuruh salah satu siswa di setiap kelompok untuk menyelesaikan hasil diskusinya ke depan kelas dan menjelaskan maksud dari soal cerita matematika tentang FPB dan KPK kepada teman-teman kelompok yang lain ( pemodelan)

i. Setelah seluruh kelompok membacakan dan menunjukkan hasil diskusi jawaban tentang soal cerita FPB dan KPK, maka guru menjelaskan kembali soal cerita FPB dan KPK yang benar melalui tahapan-tahapan implementasi agar siswa dapat dengan sendirinya mamahami maksud dari penjelasan guru (refleksi)

j. Kemudian guru menyuruh siswa kembali mengerjakan soal cerita FPB dan KPK, sesuai dengan dari penjelasan guru dalam refleksi tadi untuk mengukur kemampuan siswa menjawab soal cerita (penilaian nyata)

k. Guru bersama dengan siswa membahas hasil tes yang diberikan

1. Guru memberikan penilaian terhadap tiap-tiap kelompok

\section{Pengamatan}

Kegiatan yang dilakukan pada tahap ini adalah:

- Melaksanakan pengamatan terhadap pelaksanaan dan proses pembelajaran dengan menggunakan lembar observasi yang telah disiapkan. Observasi dilakukan selama proses pembelajaran berlangsung.

\section{Refleksi}

Refleksi dilakukan berdasarkan hasil analisis data, baik data hasil observasi maupun data hasil evaluasi.Refleksi ini dilakukan dengan tujuan untuk menilai apakah tindakan penggunaan pendekatan kontekstual sudah berjalan lancar optimal dalam meningkatkan hasil belajar siswa.Dan yang terpenting untuk mempelajari kelemahan dan memungkinkan pengembangan pada siklus berikutnya.

\section{Siklus II}

\section{Tahap Perencanaan}

Adapun kegiatan perencanaan pada siklus ini antara lain ialah :

a. Mengidentifikasi masalah yang muncul pada siklus I dan yang belum teratasi

b. Menetapkan alternatif pemecahan masalah

c. Pengembangan materi dan program tindakan pada siklus II

\section{Tahap pelaksanaan}

Adapun langkah-langkah kegiatan dalam pelaksanaan tindakan ini yakni sebagai berikut:

a. Guru melakukan apersepsi

b. Guru menjelaskan materi pelajaran

c. Guru membagi siswa ke dalam 7 kelompok yang terdiri dari 5 orang dalam 1 kelompok

d. Guru menjelaskan tentang materi soal cerita matematika dalam FPB dan KPK (konstruktivisme)

e. Guru menyuruh siswa mencari maksud dari pertanyaan dalam soal cerita (inkuiri)

f. Guru memberikan kesempatan kepada siswa untuk menanyakan 
kembali penjelasan dari soal cerita yang di sampaikan (bertanya)

g. Guru mulai memperhatikan kerja siswa dengan mengisi lembar observasi

h. Guru menyuruh salah satu siswa di setiap kelompok untuk menyelesaikan hasil diskusinya ke depan kelas dan menjelaskan maksud dari soal cerita matematika tentang FPB dan KPK kepada teman-teman kelompok yang lain ( pemodelan)

i. Setelah seluruh kelompok membacakan dan menunjukkan hasil diskusi jawaban tentang soal cerita FPB dan KPK, maka guru menjelaskan kembali soal cerita FPB dan KPK yang benar melalui tahapan-tahapan implementasi agar siswa dapat dengan sendirinya mamahami maksud dari penjelasan guru (refleksi)

j. Kemudian guru menyuruh siswa kembali mengerjakan soal cerita FPB dan KPK, sesuai dengan dari penjelasan guru dalam refleksi tadi untuk mengukur kemampuan siswa menjawab soal cerita (penilaian nyata)

k. Guru bersama dengan siswa membahas hasil tes yang diberikan

1. Guru memberikan penilaian terhadap tiap-tiap kelompok

\section{Tahap pengamatan}

Kegiatan pada tahap ini sama dengan kegiatan pada siklus I yakni observer mengamati aktivitas guru dan siswa di kelas selama pembelajaran berlangsung dengan menggunakan lembar observasi yang telah dipersiapkan peneliti sebelumnya.

\section{Tahap refleksi}

Dari tes dan observasi yang telah diberikan sebagai dasar mengambil kesimpulan, apakah kegiatan yang dilakukan telah berhasil atau belum.

Jika siklus II belum berhasil maka akan direncanakan siklus selanjutnya. Namun jika telah memenuhi indikator keberhasilan belajar, maka tidak perlu dilanjutkan ke siklus berikutnya.

Refleksi dilakukan pada akhir siklus II.Kegiatan ini dilakukan untuk melihat hasil perkembangan pelaksanaan dan membuat kesimpulan mengenai kekurangan dan kelebihan yang dilakukan.

\section{Alat Pengumpul Data}

Dalam penelitian perlu memiliki teknik dan alat pengumpul data yang relevan. Untuk mengumpulkan data yang dapat diperoleh dengan teknik berikut:

a. Observasi terhadap kelas yang bermasalah. Observasi dilakukan pada aktivitas siswa selama kegiatan berlangsung.

b. Memberi tes tentang soal cerita dalam FPB dan KPK kepada siswa yang berbentuk tes tertulis.

\section{Insrtument Penelitian}

Insrument penelitian dalam penelitian ini sebagai berikut:

\section{Observasi}

Observasi dilakukan ketika siswa berbicara di depan kelas dan proses pembelajaran berlangsung. Pada saat siswa berbicara di depan kelas, 
peneliti menilai siswa dengan indikator memahami soal cerita matematika yaitu: ketepatan mencari nilai manakah yang FPB dan KPK. Pada proses pembelajaran berlangsung, peneliti mengobservasi keaktifan siswa, rasa antusias (semangat), siswa dalam proses belajar mengajar dan kondisi kelas yang kondusif. Hasil dari observasi tersebut dijadikan peneliti sebagai sumber masukan untuk memperbaiki proses belajar mengajar disetiap siklus.

Tes

Salah satu yang dilakukan untuk mengukur kemampuan dan melihat kemampuan serta melihat tingkat keberhasilan siswa adalah tes.Tes yang diberikan berupa tes tertulis berbentuk soal cerita matematika.

\section{Teknik Analisis Data}

Tehnik pengumpulan data pada penelitian ini adalah dengan menggunakan analisis data kualitatif. Dimana penelitian ini lebih menitikberatkan pada kualitas, proses pembelajaran dan keterkaitan antara kegiatan yaitu pemahaman pada soal cerita matematika pada soal FPB dan KPK pada mata pelajaran Matematika dengan menggunakan pendekatan Contextual Teaching and Learning (CTL). Adapun analisis data yang dipakai adalah sebagai berikut :

Pada siklus dideskripsikan jumlah skor yang diperoleh semua siswa, daya serap, dan rata-rata skor untuk aspek kelancaran berbicara, ketepatan pilihan kata (diksi), struktur kalimat, kelogisan (penalaran), dan kontak mata.Selain itu juga, juga dideskripsikan jumlah skor, jumlah nilai, rata-rata nilai, dan tingkat daya serap, dan ketuntasan belajar siswa pada setiap siklus.Hal ini dapat dilihat dari berapa persenkah tingkat keberhasilan yang dicapai dilihat dari perubahan keterampilan berbicara siswa.

\section{Observasi}

Analisis untuk observasi digunakan Rumus:

$$
\mathrm{Pi}=\frac{\Sigma B}{N}
$$

Keterangan:

$\mathrm{Pi}=$ Hasil Observasi

$\mathrm{B}=$ Skor observasi

$\mathrm{N}=$ Jumlah item observasi

Kriteria yang digunakan:

$$
\begin{aligned}
& 0-1=\text { Kurang } \\
& 1,1-2=\text { Cukup } \\
& 2,1-3=\text { Baik } \\
& 3,1-4=\text { Sangat Baik }
\end{aligned}
$$

\section{Hasil Tes}

1. Hasil Belajar Individu

Hasil Belajar $=$

$$
\frac{\text { Skor yang diperoleh siswa }}{\text { Skor maksimal }} \times 100
$$

Anitah (dalam Wina Sanjaya 2008:1.20)

Kriteria peniaian yang digunakan adalah:

Nilai $<65=$ Siswa tidak tuntas dalam belajar

Nilai $\geq 65=$ Siswa tuntas dalam belajar

2. Nilai Rata-Rata Klasikal

Untuk mengetahui Nilai Rata-rata Klasikal digunakan rumus:

$$
\bar{X}=\frac{\sum F x}{\sum N}
$$

Keterangan:

$\mathrm{X}=$ Nilai rata-rata Klasikal

$\mathrm{Fx}=$ Nilai Siswa 
$\mathrm{N}=$ Jumlah siswa

3. Persentase Ketuntasan Klasikal Untuk Mengetahui Persentase Ketuntasan Klasikal Digunakan Rumus:

$$
\mathrm{PKK}=\frac{F}{N} \mathrm{X} \quad 100 \%
$$

Keterangan :

PKK $=$ Persentase Ketuntasan Klasikal

$\mathrm{F}=$ Siswa yang mengalami perubahan

$\mathrm{N}=$ Jumlah Seluruh siswa

Ketentuan untuk Ketuntasan Klasikal adalah :

$$
\text { PKK }<85 \%=\text { Belum Tuntas }
$$$$
\text { PKK } \geq 85 \%=\text { Tuntas }
$$

\section{Pembahasan}

Berdasarkan hasil pelaksanaan dan pembahasan selama melaksanakan penelitian di SD, maka dapat diketahui dengan menggunakan pendekatan pembelajaran Contextual Teaching And Learning (CTL) pada penyelesaian soal Cerita Matematika tentang FPB dan KPK dapat meningkatkan hasil belajar siswa. Selama penelitian ini berlangsung, secara bertahap siswa memiliki kemauan untuk mengikuti kegiatan pembelajaran yang dilakukan peneliti, serta siswa merasa senang dengan sistem belajar yang diterapkan peneliti, dimana dengan menggunakan pembelajaran CTL siswa merasa tertarik dan siswa mulai fokus terhadap apa yang diajarkan peneliti.

Berdasarkan hasil analisis data oleh penelitian dapat dikemukakan halhal sebagai berikut: a. Sebelum diberikan tindakan siswa diberikan test awal (pre-test). Dari test awal yang telah dilakukan maka didapat nilai rata-rata kelas 49.71 dan 2 orang siswa dari 35 jumlah siswa keseluruhan yang mendapatkan nilai ketuntasan yang telah ditetapkan, dengan persentase ketuntasan kelas $5,71 \%$. Hasil yang didapat masih sangat jauh dari nilai ketuntasan yang ingin dicapai oleh peneliti yakni nilai rata-rata kelas 6,5 dengan persentase ketuntasan kelas $85 \%$.

b. Berdasarkan pada test awal maka dilaksanakan tindakan dengan menggunakan pendekatan Contextual Teaching and Learning (CTL) pada penyelesaian soal cerita matematikadengan menggunakan FPB dan KPK. Kemudian setelah itu peneliti melakukan post-test siklus I untuk mengetahui tingkat keberhasilan belajar siswa.

c. Berdasarkan hasil post-test siklus I telah terdapat kemajuan dari perolehan hasil belajar siswa dari test awal sebelumnya dimana pada siklus I nilai rata-rata kelas 68,86 dengan persentase ketuntasan kelas adalah $60,00 \%$.

d. Berdasarkan analisis data dan hasil observasi pada siklus I diperoleh kesimpulan sementara bahwa dengan menggunakan pendekatan Contextual Teaching and Learning (CTL) yang dilakukan peneliti hasil belajar siswa mengalami peningkatan yang signifikan namun belum optimal sehingga perlu perbaikan dan pengembangan pembelajaran pada siklus II. 
e. Pelaksanaan tindakan pada siklus II merupakan perbaikan kegiatan pembelajaran yang dilaksanakan pada siklus I. Peneliti berusaha sebaik mungkin memberikan pengarahan dan penjelasan kepada siswa agar seluruh isi materi yang diajarkan dapat dimengerti dan dipahami oleh siswa. Pelaksanaan pada siklus II hasil yang didapat menunjukkan hasil yang memuaskan, dimana nilai rata-rata kelas mencapai 87,71 dengan persentase ketuntasan klasikal mencapai 91,43\%. Hasil observasi pada siklus II menunjukkan bahwa kegiatan pembelajaran dengan menerapkan pendekatan Cuntextual Teaching and Learning (CTL) semakin baik dan optimal.

Tabel Rata-Rata Kelas Dan

Persentase Ketuntasan Klasikal Pada Setiap Test

\begin{tabular}{|c|c|c|c|}
\hline No & Tes & $\begin{array}{c}\text { Rata-rata } \\
\text { Kelas }\end{array}$ & $\begin{array}{c}\text { \% } \\
\text { Ketuntasan }\end{array}$ \\
\hline 1 & Pre-Test & 49,71 & $5,71 \%$ \\
\hline 2 & $\begin{array}{c}\text { Post-Test } \\
\text { Siklus I }\end{array}$ & 68,86 & $60,00 \%$ \\
\hline 3 & $\begin{array}{c}\text { Post-Test } \\
\text { Siklus II }\end{array}$ & 87,71 & $91,34 \%$ \\
\hline
\end{tabular}

\section{Grafik Rata-Rata Kelas Pada Setiap} Tes
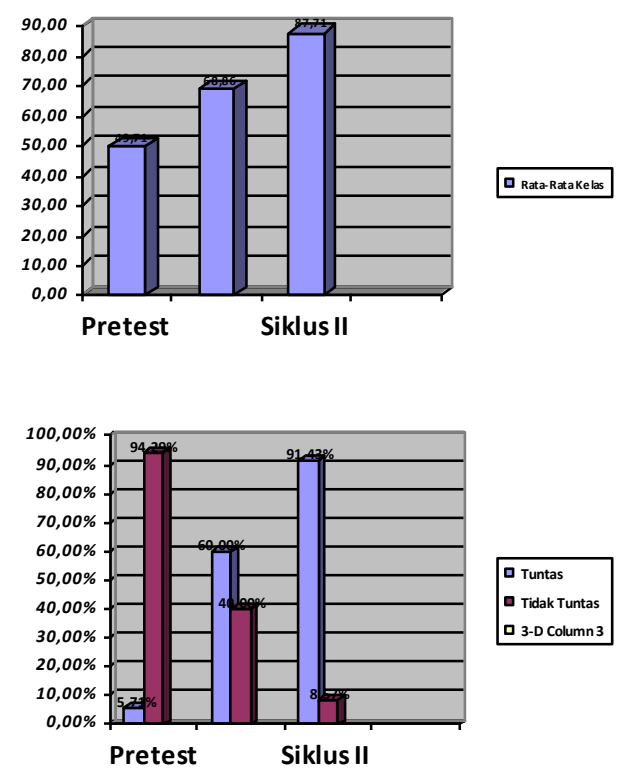

Grafik Persentase Ketuntasan Kelas Pada Setiap Tes

\section{SIMPULAN DAN SARAN}

\section{Simpulan}

Beberapa kesimpulan yang dapat ditarik dari hasil penelitian ini adalah :

a. Hasil pre-test yang dilakukan pada kegiatan awal yaitu nilai rata-rata kelas adalah 49,71 dan siswa yang tuntas belajar hanya 2 orang siswa $(5,71 \%)$

b. Setelah pelaksanaan siklus I dengan menerapkan pendekatan Contextual Teaching And Learning (CTL) diperoleh hasil penilaian yaitu nilai rata-rata kelas adalah 68,86 dengan ketuntasan klasikal 60,00 \%. Peningkatan hasil belajar pada siklus I adalah 54,29\%.

c. Setelah pelaksanaan siklus II dengan menerapkan pendekatan Contextual Teaching And Learning (CTL) yang lebih baik dan optimal diperoleh hasil penilaian yaitu nilai rata-rata kelas adalah 87,71 dengan ketuntasan klasikal 91,43 \%. Peningkatan hasil belajar pada siklus II adalah 31,43\%.

d. Pembelajaran dengan menggunakan pendekatan Contextual Teaching And Learning (CTL) dapat meningkatkan hasil belajar siswa kelas V Sekolah Dasar dalam menyelesaikan soal cerita matematika dengan menggunakan kelipatan persekutuan 
terkecil (KPK) dan faktor persekutuan terbesar (FPB).

\section{Saran}

Adapun saran yang dapat dikemukakan dalam penelitian ini adalah sebagai berikut:

a. Dalam proses belajar mengajar guru hendaknya menggunakan pendekatan pembelajaran Contextual Teaching And Learning (CTL) agar siswa lebih memahami isi materi pelajaran yang disampaikan oleh guru dan lebih aktif.

b. Kepala Sekolah hendaknya memperhatikan penggunaan pendekatan pembelajaran Contextual Teaching And Learning (CTL) pada kegiatan pembelajaran di sekolah agar proses pembelajaran lebih efektif, variatif, dan inovatif.

c. Siswa diharapkan lebih teliti dalam mengerjakan soal cerita matematika dan berperan aktif dalam setiap kegiatan pembelajaran.

d. Penelitian ini diharapkan dapat dijadikan refrensi bagi peneliti lain yang ingin meneliti kembali tentang menggunakan

e. Pendekatan pembelajaran Contextual Teaching And Learning (CTL) dalam menyelesaikan soal cerita matematika tentang FPB dan KPK di Kelas V Sekolah Dasar.

\section{DAFTAR RUJUKAN}

Arikunto, Suharsimi. 2006. Prosedur Penelitian Suatu Pendekatan Praktek. Jakarta: Rineka Cipta.

Departemen Pendidikan Nasional. 2006. Kurikulum Tingkat Satuan
Pendidikan 2006. Jakarta:

Depdiknas

Dimyati \& Mudjiono, 2009. Belajar dan Pembelajaran. Jakarta: Rineka Cipta.

Djamarah, Syaiful Bahri. 2006. Strategi Belajar Mengajar. Edisi Revisi, cet. Ke 3. Jakarta: Rineka Cipta. 2008. Psikologi belajar. Edisi revisi cet. Ke 2. Jakarta: Rieneka Cipta.

Heruman. 2007. Model pembelajaran Matematika Di Sekolah Dasar. Bandung: Rosda.

Kunandar. 2007. Guru Profesional. Jogjakarta: Raja Grafindo Persada.

Nasution. 2000. Berbagai pendekatan dalam proses belajar dan mengajar. Jakarta. Bumi Aksara.

Sanjaya, Wina. 2008. Kurikulum dan pembelajaran. Jakarta: Kencana.

Sudjana, Nana. 2010. Penilaian hasil Proses Belajar Mengajar. Jakarta: Remaja Rosda.

Sudrajat, Akhmad. 2008. Pengaruh Kinerja Guru Terhadap Motivasi Belajar Siswa. (online). Tersedia $\quad$ http://www.umpwr.ae.id/web/publikasi ilmiah/410-analisis-pengaruhkinerja-guru-terhadap-motivasibelajar-siswa.html. (17 Februari 2010)

Suprijono, Agus. 2010. Cooperative Learning Teori \& Aplikasi Paikem. Yogyakarta: Pustaka Pelaja 
